\title{
The First Testament in the Gospel of Matthew 1
}

\author{
Andries van Aarde \\ Department of New Testament Studies (Sec A) \\ University of Pretoria
}

\begin{abstract}
Matthew is to be read as a narration with an ongoing plot and an open end. There is a correlation between the (post-paschal) Jesus' commission and the risen Jesus' presence in his disciples' (post-paschal) commission until the parousia. This insight amounts to the fact that the plot of Matthew is continuing after its apparent conclusion, only to be resolved in its implied continuation. The intention of the paper is to describe, against the background of the debate among Matthean scholars, the function of the use of the First Testament in the light of the abovementioned two sequences. The term 'First Testament' in this instance is not restricted to the Hebrew canon but also includes some pseudepigrapha which were not considered as 'outside a canon' either by the synagogue or the church, for example 1 Enoch, 2 Baruch, The lives of the prophets and Pseudo-Philo.
\end{abstract}

\section{INTRODUCTION}

The Gospel of Matthew is to be read as a narration with an ongoing plot and an open end. The plot of Matthew's story about Jesus consists of a correlation between the earthly Jesus' commission and the risen Jesus' presence in the (post-paschal) commission of the disciples until the coming of the parousia. The author wrote his gospel from a retrospective viewpoint. This after-the-event point of view enabled the narrator to provide the plot in the Matthean story, from the perspective of reader involvement, an effective open end. Willi Marxsen (1959:63f), who points out in his well-known work on the Gospel of Mark some of the most important characteristics of the other two synoptic gospels as well, makes the following reference to the open-endedness of the Gospel of Matthew: Where Mark wrote against the background of an anticipation

* Paper presented at the Colloquium Biblicum Lovaniense, Katholieke Universiteit Leuven, Belgium, July 31, 1996. Financial assistance from the Centre for Science Development is hereby acknowledged. 
of Jesus' early return, Matthew began to allow for a possible delay in his return. He offered an interim solution. He enlarged upon the commission theme, which was also present in Mark (cf Mk 13:10), to make it an independent epoch with a typical Matthean function, which was to make disciples of all people (cf Mt 28:16-20). This period of the disciples' commission follows the 'time' of Jesus. It extends from Jesus' resurrection from the dead to the 'time' of Matthew himself. It goes even further. It actually extends into our time. The end of Matthew's gospel is thus open since, after the conclusion of the epoch of Jesus, another began which continues up to the end of time.

The above insight amounts to the plot of Matthew's story continuing after its apparent conclusion, and only being resolved in its non-explicit continuation. The intention of this paper is to describe the function of the use of the First Testament in the light of the two 'temporal' sequences in the plot of the Gospel of Matthew, against the background of the debate among Matthean scholars. However, to restrict the term 'First Testament' to the Hebrew canon is historically anachronistic prior to C E 100 (cf Charlesworth (1985:xxiv). During this period, in which the limits of the Hebrew canon were still fluid, some pseudepigrapha were composed which were not considered by both the synagogue and the church as 'outside a canon' (Charlesworth 1985:xxiii). This is specifically true with regard to the Gospel of Matthew. For example, the author of the First Gospel was familiar with traditions in, among other writings, 1 Enoch (cf Isaac 1983:10), 2 Baruch (cf Waetjen 1976:49-52), The lives of the prophets (cf Garland 1995:260; Hare 1985:393) and Pseudo-Philo (cf Harrington 1985: 302). In these documents intertextual parallels with regard to messianic eschatological symbolism resembling each other. 2 Baruch is very important, for it shares with Matthew an intention to cope with the 'eschatological meaning' of the temple after the catastrophe of C E 70 and with the emergence of formative Judaism (cf Klijn 1983: 620). In both the Gospel of Mathhew and in 2 Baruch the history of Israel is interpreted by means of apocalyptic imagery in the light of the destruction of the temple (cf Saldarini 1994:14). However, it is difficult, almost impossible, to prove dependency on the part of the Gospel of Matthew. It is, as Kliijn (1983:619) argues with respect to 2 Baruch, a common 'dependency on apocalyptic imagery'. The expression 'First Testament', therefore, refers in this paper to the scriptural witnesses of Israel's history and not to a canonical codification.

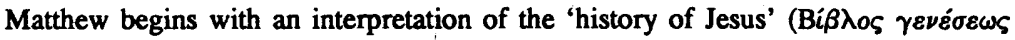
'I $\eta \sigma o \hat{v} \mathrm{X} \rho \iota \sigma \tau o \hat{v})$ as part of Israel's history. The course of Israel' history is symbolically divided into three sections of fourteen generations each (Waetjen 1976:49-52). This genealogical table of Jesus, comprising 3x14 generations (Mt 1:1-17), parallels the eschatological interpretation of Israel's history in the Messiah Apocalypse of 2 Baruch 
53-74 (the time from Abraham to David, from David to the Babylonian exile, from the Babylonian exile up to and including the Messiah). Unlike Luke, Matthew does not begin with the history of Israel just to drop it again as something of the past and not to be regarded as a continuing sequence in his plot. What then as far as time sequence is concerned, is the function of the use of the First Testament in the Gospel of Matthew? It does not serve as the 'thesis' for Jesus' (the Messiah's) 'antitheses', nor as the 'promise' which is brought to its fullest significance through its 'fulfillment' by the Messiah.

How should the portrayal of Jesus' 'fulfillment' $(\pi \lambda \eta \rho \omega \sigma \alpha \iota)$ of the 'law and the prophets' be understood in Matthew? . My thesis is that the narrator uses the First Testament functionally in order to present his disciple/church-image (the second time sequence) as analogous to and in continuity with his Jesus-image (the first time sequence). The first time level is oriented towards and paralleled by the second. Jesus is 'God-with-us' in the first sequence and he is 'God-with-us' in the second. This expression has been taken from the world of the First Testament. Matthew's clarifying clause, ö $\dot{\varepsilon} \sigma \tau \iota \nu \mu \varepsilon \theta \varepsilon \rho \mu \eta \nu \varepsilon v o ́ \mu \varepsilon \nu o \nu \mu \varepsilon \theta$ ' $\dot{\eta} \mu \hat{\omega} \nu$ o $\theta \varepsilon o ́ \varsigma$ (Mt 1:23b), resembles Isaiah (LXX) 8:8, 'which, being interpreted, means, With us is God' (see Allison, Jr 1993: 154). What is at stake in the Matthean birth story with regard to this Leitmotiv, is probably a Moses typology, as can be observed in Exodus 4:16 and 7:1. Moses is obviously not identified with God in these verses, but he clearly 'play(s) the role of God' (Allison, Jr 1993:154; cf Meeks 1970:354-371). Matthew parallels the popular expansions on Exodus about the birth of Moses which were known in the first century as can be seen in Josephus' Antiquities of the Jews (4.254-59) and in Pseudo-Philo's Liber Antiquitatum Biblicarum (9.2-10) (cf Crossan 1986:18-27; 1994:62-66).

\section{THE NARRATIVE POINT OF VIEW REGARDING THE FIRST AND SE- COND SEQUENCES}

Strictly speaking, there are three temporal sequences in the Gospel of Matthew. These are the sequence of the pre-paschal events, the sequence of the post-paschal events up to the parousia and the sequence known as, inter alia, $\dot{\eta} \zeta \omega \dot{\eta}$ in the Gospel of Matthew

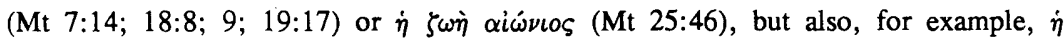

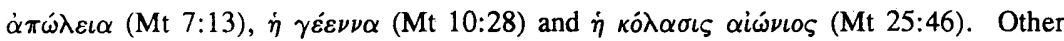
'places' that refer to this 'time' are found in Matthew 3:12, 5:22, 18:8, 9, 24:51, $25: 10,23,30,34,41$ and 26:28. According to Matthew's apocalyptic conception this is the 'time' that begins with the parousia or at someone's death (Mt 22:23-33). This third sequence is mentioned in Matthew's gospel alone (chiefly in parables), but not expanded upon. For this reason the poetics of the Gospel of Matthew display only two basic temporal levels, namely the sequence of the pre-paschal events and the sequence 
of the post-paschal events. The following temporal phrases mark the time that concludes with Jesus' resurrection and his appearance and commission to the disciples: $\dot{\varepsilon} \nu$

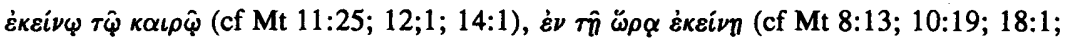

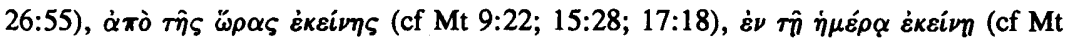

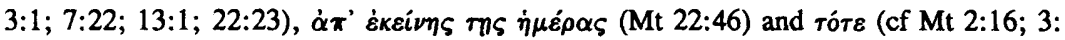
$13 ; 4: 1$ ). The participles using 'time' to depict circumstances in Matthew $2: 1,13,19$ and 4:12 can be added to the above temporal phrases. The following phrases again mark the end of the post-paschal disciples' commission, that is, the parousia: $\tau \varepsilon \lambda \operatorname{los}_{\text {(cf }}$

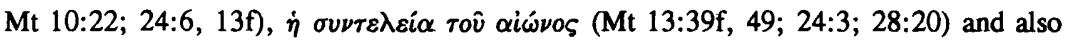

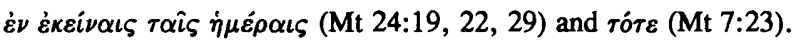

There is a continuity as well as an analogy between the Jesus commission (the first sequence) and the disciples' commission (the second sequence). The first temporal level is oriented towards the second. This relationship can therefore be typified as that of a transparency. In the transmission, conversion and re-interpretation of earlier traditions (oral and written) the Jesus era is transposed to the early church era in such a way that two historical worlds are simultaneously taken up as a narrative entity in the gospels. The story in a gospel thus concerns people and things from an earlier time while the later period in which the gospel arose and communicated is transparent in the text. A gospel thus simultaneously refers to two 'real' worlds. In the gospels the prepaschal world of Jesus, the disciples and the others is generally the most transparent. Nevertheless, the world of the post-paschal church is more transparent in some passages. The one world is never manifested totally isolated from the other. The world of the early church and that of Jesus and the disciples are, in a dialectical sense, simultaneously taken up in the gospel as a narrative record. These two worlds are presented in accordance with the narrator's 'ideological' perspective. Exactly what the continuity and analogy between the 'history of Jesus, the Messiah', and the 'history of the church' involve should be defined from the ideological perspective of the narrator. Ulrich Luz (1994:55), in respect of a quite different issue, suggests the same idea as follows: '... Matthew links the church exclusively with the earthly Jesus .... because Matthew has a narrative theology. He tells the story of Jesus. In this story, the church does not simply exist but becomes the church, because Jesus, who heals his people, shares his power with his disciples and gives them a task'.

The ideological level is basic to all other levels in the narrative (cf Uspensky. 1973: 8-9). These levels include characterization, the way characters act, speak, feel and think, as well as the temporal sequences and spatial order in terms of which the characters move, as the plot of the narrative develops. In 'religious' literature, as in Matthew's gospel, the 'ideological' perspective is to be seen as 'theological' of nature. In 
the Gospel of Matthew the ideological/theological perspective of the narrator coincides with the narrated perspective of the protagonist (cf Van Aarde 1994:35ff). This phenomenon boils down to the fact that all events, places, characters, and the like being presented from one consistent perspective, that is from that of one character, Jesus, who is called the Messiah. This single dominant perspective resounds through every episode in the narrative. By means of this technique the narrator 'lures the reader into ... times, and places by perspectively locating himself [or herself] and the reader in the midst of the scenes and events he [or she] describes, enabling the reader to see, hear, and know things he [or she] would not have access to without the narrator's guiding voice' (Petersen 1980:36-38).

The plot of the Gospel of Matthew is, as indicated, characterized by two 'lines of actions', or 'narrative lines', that of the pre-paschal Jesus-commission (the primary sequence) and that of the post-paschal disciple-commission (the secondary sequence). The dominant perspective in the theology of the Gospel of Matthew is that from which the narrator accomplishes the analogy and association between the events of these two 'lines of action'. Seen thus, the continuity and analogy between the first and the second sequence is based on the narrator's image of Jesus as Immanuel. Jesus is Godwith-us in the first sequence and he is God-with-us in the second. Kingsbury (1973: 471) describes this analogy as follows: '[T]he coalescence of the time of Jesus and the "time of the Church" in the theology of Mt. is, ultimately, christologically motivated and has its roots in the pre-Easter - post-Easter continuity of the person of Jesus ....'

Thus, the ideological/theological perspective of the narrator is closely associated with the expression God-with-us which occurs explicitly at the beginning (Mt 1:23), middle (Mt 18:19f) and end (Mt 28:18ff) of the Gospel of Matthew. Matthew's gospel relates that God came to the world from his domain, the kingdom of heaven. Instead of manifesting himself in the temple, which had been his dwelling place among his people, but which had degenerated (cf Lohmeyer 1942:109f) as a result of the actions of the Israelite elites (cf Mt 21:12ff) and occupants of Moses' cathedra (cf Mt 23:2), he became God-with-us in Jesus, the Messiah/Son of Man, the Son of God, who is 'greater than the temple' (Mt 12:6). This Jesus-mission had the purpose of forgiving the sins of all people outside the structures of the temple, especially those of the outcasts within the Israelite crowds, the 'lost sheep of Israel', but also the Gentiles (Mt 1:21; 3:6; 9:13 - cf Saldarini 1994:75), as 'sinners' - the new eschatological community (Lohmeyer 1942:60ff). Jesus did this by executing the will of the Father with total obedience, so as to 'fulfill all righteousness'. (Mt 3:15). Theoretically, the 'will of the Father' is the 'law and the prophets' (Mt 5:17), and this turns into practice (cf Stanton 1992:383) 
when there is compliance with the radical demand for love (Mt 19:19b, 21; 22:37-40). It is in this sense that Gibbs (1968) refers to the Matthean Jesus as the 'Torah incarnate'. 'For Matthew, love is the criterion for truth and falseness of faith and also for real understanding' (Luz 1994:95)

Although Jesus had already called disciples at the commencement of his work among the Jewish crowds and the gentiles, and had made them 'fishers of human beings' (Mt 4:19) to assist him, their mission into the world only began with Jesus' resurrection from the dead. The disciples were commissioned to teach and the content of their commission was the 'law and the prophets', which was the will of the Father as interpreted and embodied by Jesus himself. Matthew makes no distinction between the law and the prophets (Saldarini 1994:161). The continuing presence of the risen Jesus as God-with-us until the end of the world became visible in the obedience of the disciples who, in executing their commission to make disciples of others, were doing God's will just as Jesus did.

\section{THE ESCHATOLOGICAL TURNING OF THE TIDE}

Turning again to Marxsen' contribution, he does not note a correlation between the 'time of Jesus' and the 'time of the church' in the Gospel of Matthew (Marxsen 1959: 64). Furthermore, he considers that Matthew wrote his gospel on the basis of three temporal phases. He does not consider that these three are, as we indicated above, the 'time' of the pre-paschal Jesus commission, the 'time' of the post-paschal disciples' commission and the 'time' after the parousia. In his view they consist of the 'time of the First Testament', the 'time of the earthly Jesus' (to me, the first sequence) and the 'time of the evangelist and his community' (to me, the second sequence). What is fundamental to Marxsen's theory is that a distinction has to be drawn in the Gospel of Matthew between the 'time of the First Testament' and the first temporal sequence. His view basically corresponds with that of Conzelmann (1977) in regard to Luke-Acts. According to this the 'time of Jesus' forms a central point between the 'time of the First Testament' and the 'time of the church'. Or, as Marxsen typifies it with regard to the Gospel of Matthew: the time of Jesus is an epoch between two others.

Conzelmann and Marxsen, with their viewpoints, initiated investigation into the socalled Heilsgeschichte in the theology of the Lukan and the Matthean gospels. Research has shown that the so-called Heilsgeschichte, that is the parallel between Christology and ecclesiology, forms one of the central themes, if not the most central theme, in the theology of Luke-Acts (cf Rengstorf 1969:6). This statement can to some extent also be made applicable to the Gospel of Matthew. Questions that can be disputed in this connection as far as the Gospel of Matthew is concerned, are those regarding the number of sequences that are discernible in the gospel, the articulated spot at which one 
sequence ends and another begins, and the place and nature of the time of the First Testament within the heilsgeschichtliche framework of the gospel. Although I shall be focusing my attention on the latter, the three aspects noted above are closely integrated.

While in the Gospel of Mark there are only two occurrences (Mk 1:15; 14:49) of the prediction that the 'time of Jesus' is a fulfillment of a promise, which would be the First Testament, the idea of fulfillment plays a much more prominent role in Luke and Matthew. Marxsen has shown that, just as Matthew finds a correlation between the 'time of the earthly Jesus' and the 'time of the evangelist and his community', there is a correlation between the 'time of the earthly Jesus' and the 'time of the First Testament'. He, moreover, points out that the latter correlation is expressed in the fulfillment citations in particular. The conclusion of the time of Jesus also refers to a previous beginning, namely that of the First Testament (Marxsen 1959:64). The question is that of the nature of this correlation, or continuity, which is expressed by the fulfillment citations, as well as by other First Testament citations and First Testament allusions.

I have mentioned above that there is an analogical continuity between the prepaschal Jesus commission and the post-paschal disciples' commission,. and that the continuity centers around the presence of Jesus as God-with-us. I shall now show that the First Testament is used particularly effectively by the narrator as something on which to base this continuity. Senior (1976:670) remarks correctly in this connection: 'Perhaps no evangelist performed this "ministry of continuity" with more skill than Matthew. To study his Gospel under the rubric of "continuity" is to discover the core of his message.'

With regard to the function of the use of the First Testament in the Gospel of Mark, one can remark on a difference between Mark and Matthew (cf Vorster 1981: 70). Although the use of the First Testament in both gospels functions according to the promise-fulfillment technique, this technique is implemented by the citations in the Gospel of Mark, unlike in Matthew, where the First Testament is considered fulfilled in Jesus. Willem Vorster states this as follows: '... these quotations form part of the Markan narrative of Jesus and are fulfilled in that narrative. In other words it is not the same as in Matthew's account, where the First Testament is regarded as fulfilled in Christ. In Mark's gospel these quotations are part of the narrative statement and are fulfilled within the boundaries of that text.' This reference to the Gospel of Matthew implies that the 'time of the earthly Jesus' (the first sequence) and the 'time of the First Testament' do not coincide, but that, according to Matthew, the latter would be the advance 'promise' of the former, which would then be its fulfillment. This view 
agrees with that which we find in, for example, Strecker (1966), Walker (1967) and Kingsbury (1973), while authors such as Barth (1961), McConnel (1969), Barr (1976), Senior (1976) and Aguirre (1981) do not hold the same view. Scholars such as Trilling (1969) and Meier (1975) adopt another interesting view in this connection.

I have already made the point that the poetics of the Gospel of Matthew only display two explicit temporal (and topographical) levels, namely that of the pre-paschal and that of the post-paschal. As a consequence the 'time of the First Testament' does not function as a separate sequence in the Gospel of Matthew, but is a part of the prepaschal Jesus commission. We thus differ from scholars such as Vorster, Kingsbury, Walker and Strecker with regard to the place and nature of the 'time of the First Testament' in the Gospel of Matthew. If we were to concur with these scholars in this connection, it would imply that Matthew and Luke, coincidently, broadly recognized the same heilsgeschichtliche theology. The Immanuel perspective of the narrator in the Gospel of Matthew, however, makes a heilsgeschichtliche viewpoint, such as that maintained by the above-mentioned colleagues, impossible. My own view is rather more that of, for example, Barth, Barr, Senior and Aguirre.

With regard to the very important point that features in this context, namely the point at which the first sequence switches over to the second, my view agrees with that of people such as Strecker and Walker, as well as with that of Trilling and Meier. I shall now explain my viewpoint against the background of the other opinions mentioned, and at the same time show that none of the scholars mentioned recognized the relationship between Matthew's Immanuel theology and the different temporal levels in the Gospel. This relationship simultaneously serves to explain the role and the nature of the 'time of the First Testament' in the Gospel of Matthew, as well as the paradox between the so-called particular and the universal purport in the this gospel.

Although both Strecker (1966:86-93) and Walker (1967) are greatly influenced by Conzelmann, they differ from each other in respect to certain finer details. Both, however, agree that three temporal phases can be distinguished in the Gospel of Matthew. Walker (1967:115) refers to these three temporal phases as the 'prehistory of the Messiah', which began with Abraham, the 'history of the calling of Israel' (the particular purport) which consists of the ministry of John the Baptist as the precursor of the Messiah and Jesus himself as the Mitte der Mitte, and finally the 'history of the mission to the Gentiles' (the universal purport) which began with the crucifixion and resurrection of Jesus and extends to the day of judgment and thus partly coincides with the time of the evangelist. Strecker (1966:184-188) refers to these three temporal phases as the 'time of the fathers and the prophets', the 'time of Jesus' and the 'time of the 
Heidenkirche'. Like Walker (1967:115), Strecker (1966:187) regards John the Baptist as part of the 'time of Jesus'. After Jesus' death and resurrection this 'time' went over into the 'eschatological time'.

Unlike Strecker and Walker, Kingsbury (1973:471) does not distinguish three temporal phases in the Gospel of Matthew, but two. He formulates his view as follows:

It has long been recognized that especially the formula quotations in the first Gospel reveal that Mt. has theological affinity for the categories of 'prophesy' and 'fulfilment'. These terms aptly characterize Mt's view of the history of salvation. There is the 'time of Israel', which is preparatory to and prophetic of the coming of the Messiah; and there is the 'time of Jesus ...', in which the time of Israel finds its fulfillment and which, from the vantage point of Matthew's day, extends from the beginning of the ministry of John and of Jesus (past) through post-Easter times (present) to the coming consummation of the age (future). In Mt's scheme of history, one does not, strictly speaking, find any such epoch as the 'time of the Church', for this 'time' is subsumed under the 'last days' inaugurated by John and Jesus.

(Kingsbury 1973:471)

Kingsbury differs from Strecker and Walker not with regard to the beginning of the 'time of Jesus', but with regard to the end of this 'time'. He holds the opinion that there was no change in 'time' at Jesus' death and resurrection, but that the 'eschatological time' coincides fully with the 'time of Jesus'. This 'eschatological time' begins with the commencement of John the Baptist's work. In this connection the three scholars mentioned above consider that Matthew 3:1, as the beginning of John the Baptist's service, indicates the division between the 'time of the First Testament' and the 'time of Jesus'. According to this view, the elements promise (the 'time of the First Testament') and fulfillment (the 'time of Jesus') separate the two temporal levels of time. Kingsbury (1973:470; cf Strecker 1966:87) builds his argument chiefly on the

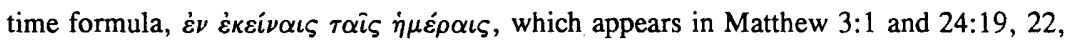
29. He considers that this time formula has an exclusive 'eschatological' connotation that refers to 'that period of time which precedes the consummation of the age and the return of Jesus, Son of Man'. Matthew thus, according to Kingsbury, employs this time formula inclusively and uses it to refer to the 'time of John the Baptist', the 'time 
of Jesus', and the 'time of the church'. And, because of this inclusiveness, the Gospel of Matthew does not, according to Kingsbury, show a separation between the 'eschatological community' and the 'time of Jesus', but a separation between the 'time of the First Testament' and the 'time of Jesus'. The latter begins with the 'time of John the Baptist'. '.. Matthew, as 11:13 indicates, sees the law and the prophets, the entire OT, as "prophesying", as pointing forward, to the events that mark the eschatological age of salvation' (Kingsbury 1977:83f).

Kingsbury (1973), like Strecker (1966), considers that the three stages in the 'eschatological time', that is to say the 'time of John the Baptist', the 'time of Jesus' and the 'time of the church', should not be seen as a progressive increase in eschatological intensity. Although various 'historical' stages are distinguishable in the 'eschatological time', these stages, according to Kingsbury and Strecker, do not represent qualitative differentiation, but rather make a qualitative whole. Strecker, unlike Kingsbury, draws a type of distinction between the 'time of Jesus' and the 'time of the church'. These two 'times' function, according to him, alongside one other in the Gospel of Matthew. He formulates this mutual impact of the two 'times' on each other by saying that the eschatological element is historicized. In other words, eschatology is consequently organized in time, as, vice versa, the story of the Jesus of history can not be understood in secular-historical categories any more, but attains an eschatological quality: 'Das eschatologische Element wird historisiert, nämlich konsequent der Zeit eingeordnet, wie umgekehrt die Historie nicht mehr in profangeschichtlichen Kategorien zu erfassen ist, sondern eine eschatologische Qualität erlangt' (Strecker 1966:185)

As far as both the beginning and end of the 'time of Jesus' is concerned, I do not regard Kingsbury as convincing. With regard to the end of the Jesus commission I have already pointed out that there is an analogy in the Gospel of Matthew between the pre-paschal Jesus commission and, in pursuance to this, the post-paschal disciples' commission ('the time of the eschatological community' - in Lohmeyer's terminology). Nevertheless these two sequences do not function as exclusive compartments. They are mutually integrated by means of thematic parallels (cf Mt 4:23; 9:35 with 10:6ff), cross-references (cf Mt 16:19 with 18:18; 23:13), prospection (cf Mt 5:12 with 23:34ff) and retrospection (cf Mt 14:13-21; 15:32-39 with 16:9ff). This mutual integration of the pre-paschal Jesus commission and the post-paschal disciples' commission relates to the comment above by Strecker, that the 'historical element' in the Gospel of Matthew has gained an eschatological quality and the 'eschatological element' has again been historicized. It is this insight which I want to express by means of the transparency concept. Aguirre (1981:152) formulates it as follows: 
Matthew contains a level of narration, grounded in tradition and embodying an historical perspective on the past - though seen through faith and hence idealized. But there is also a second level that makes this past narrative relevant to the present needs of Matthew's communiy. Though neither level of discourse is ever totally absent, in some contexts one level may take precedence over the other, and the Gospel will slip imperceptibly from one to the other.

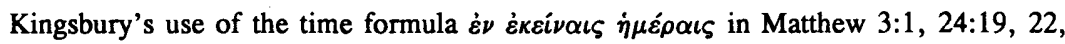
29 , to support his point of view, does not hold water here either. Similarly, this is the main reason that we differ from Kingsbury regarding the beginning of the Jesus commission. Since we do not draw a distinction between the singular form of the time formula $\dot{\varepsilon} \nu \tau \hat{\eta} \dot{\eta} \mu \dot{\varepsilon} \rho \alpha \dot{\varepsilon} \kappa \varepsilon i \nu \eta$ and the plural form $\dot{\varepsilon} \nu \tau \alpha \hat{\imath} \varsigma \dot{\eta} \mu \varepsilon \dot{\varepsilon} \rho \alpha \varsigma$, I have pointed out that this time formula marks both the first sequence (Mt 3:1; 7:22; 13:1;22:23) and the end of the second sequence (Mt 24:19, 22, 29). The time formula concerned has in other words an eschatological connotation in the so-called eschatological discourse (chapters 23-25), but not in Matthew 3:1. Kingsbury therefore integrates the pre-paschal Jesus commission with the post-paschal disciples' commission, with the result that the continuity and analogy between them are thereby lost.

It is therefore important to realize that the shift between these two sequences takes place at Jesus' crucifixion and resurrection. Trilling (1969a, 1969b), in two separate articles, has convincingly shown that the 'Wende der Zeit' takes place at this point in the Gospel of Matthew (cf Meier 1975:207). He writes in the first article that Matthew 27:51ff is highly remarkable, since the death of Jesus not only causes the veil to tear which signifies according to The lives of the prophets [Habakkuk] 12:11-12 God's judgment of the temple cult (Garland 1995:260), the end of the old cultic order - but also causes earthquake (see Zechariah 14:4) and the resurrection of the death (see Ezekiel 37:13-14 and 1 Enoch 51:1-2). These are eschatological signs: The earthquake belongs to the apocalyptic elements; it marks the beginning of the end and the rearrangement of the world (Trilling 1969a:195; Allison, Jr 1985:40-46). The same point of view is expressed in the second article of Trilling when he states that, in regard to Matthew 27:51f, these verses can only be seen as an announcement, through the death of Jesus, of the beginning of the new aeon, a change that encloses the whole cosmos. It is a dramatic anticipation of Jesus' resurrection in the story of Jesus' death. It announces the destruction of the oid and the dawning of the new time (Trilling 1969b:221f; cf Waetjen 1976:248). 
Because of difference with Kingsbury in this important matter regarding the eschatological turning of the tide in the Gospel of Matthew, I consider that he mistakenly. wishes to separate the 'time of the First Testament' from the time of the earthly Jesus as Immanuel (the first sequence) and, as far as I am concerned, also from the time of the risen Jesus as Immanuel (the second sequence).

Meier (1975:207; 1976:30-35) also considers that the crucifixion and resurrection of Jesus introduces the 'Wende der Zeit'. He, however, holds the view that there is a radical distinction between the 'old time' and the 'new time'. He equates the 'old time' with the 'time of the First Testament' and thus the demand for obedience to the Mosaic law and the time of Jewish particularism. He equates the 'new time' with the period of the universal purport, which began with the death and resurrection of Jesus and was foreshadowed during the 'old time', as it can be seen in texts such as Matthew 8:5-13 and 15:21-28. Meier builds his argument chiefly on the baptismal command to the disciples with regard to the $\pi \dot{\alpha} \nu \tau \alpha \tau \dot{\alpha} \check{\varepsilon} \theta \nu \eta$ (Mt 28:19). According to him baptism replaces circumcision, which symbolized the 'old time'. Just as the particular purport went over into the universal, the demand for obedience to the Mosaic law, according to Meier, falls away with Jesus death and resurrection. Variations on this view are encountered in Trilling (1964:211), Hamerton-Kelly (1972) and Waetjen (1976:244). The latter, despite so many meritorious insights in his book, The origin and destiny of humanness, with regard to First Testament allusions in the Gospel of Matthew, uses misleading expressions like: 'The death of Jesus is also the death of Israel' (Waetjen 1976:248) and ' $(T)$ he promises of the Old Testament have been fulfilled and cancelled at the same time' (Waetjen 1976:244).

What these scholars do not take into account, however, is that the use of the First Testament in the Gospel of Matthew can be seen as a narrative technique which principally has the same function as narrator's commentary. Narrator's commentary serves the reader as an important directive to read the narrative as the narrator intends it to be read. The introductory formula of the fulfillment citations can, seen thus, be regarded as the introduction to the narrator's commentary. Graham Stanton (1992:348) calls this introductory formula ""asides" of the evangelist' which 'are not placed on the lips of Jesus or of other participants in the evangelist's story'. By means of scriptural proof and fulfillment citation the First Testament functions in the Gospel of Matthew as the narrator's commentary, on which he bases the continuity and analogy between the prepaschal Jesus commission and the post-paschal disciples' commission. This continuity and analogy lies in the presence of Jesus as God-with-us on both temporal levels. And Jesus' Immanuel nature is manifested in his absolute obedience to the will of the Father (the 'law and the prophets'). David Barr (1976:357f), therefore, rightly remarkes that 
the relationship between prophesy (the 'time of the First Testament') and fulfillment (the 'time of Jesus' and the 'time of the church') is not one of antithesis, but one of completion.

Just like Barr, Senior (1976:672f) also considers that Matthew uses the First Testament to build a continuity and analogy between his Jesus-image (first sequence) and his disciple/church-image (second sequence). One finds the same conviction in Aguirre's (1981) article on the interrelationship between 'cross' and 'kingdom' in Matthew's theology. The result of my investigation largely agrees with their views on the levels of the pre-paschal Jesus commission and the post-paschal disciples' commission. I shall now give a short explanation of this result.

\section{THE FUNCTION OF THE USE OF THE FIRST TESTAMENT}

The Gospel of Matthew is circumscribed by Jesus' birth record (Mt 1:2-17) and the commission to the disciples (Mt 28:16-20). The genealogical register relates Jesus' divine legitimacy and royal ministry to Mosaic kingship and covenantal kinship in the First Testament - being Son of God, Son of Abraham and of David, born in Bethlehem; Immanuel, the 'new Moses'. The commission of the disciples relates the ministry of 'sons of God' and 'brothers of each other' in the $\dot{\varepsilon} \kappa \kappa \lambda \eta \sigma i \alpha$ with that of Jesus. In effect, the pre-paschal Jesus commission and the post-paschal disciples' commission are both linked to the First Testament (the 'law and the prophets'). In terms of traditional theologoumena this means that the theology of the Gospel of Matthew is neither ecclesiological (cf e g Strecker 1966) nor christological (cf e g Kingsbury 1975), but that ecclesiology and christology, as a result of the God-with-us perspective of the Gospel of Matthew, are a two-part unit (cf e $g$ Frankemölle 1974:230, 239, 243). On the levels of both the pre-paschal Jesus commission and the post-paschal disciples' commission the First Testament (the 'law and the prophets') functions as the directive medium. This statement can be debated as follows.

Matthew 5:17-20 functions in the gospel as the key to the lasting validity of the kerygma in the First Testament. Jesus did not come to make the First Testament invalid and replace it, but to illustrate its 'true meaning' in his actions and disposition, and thus 'fulfill' it. This disposition contrasts, according to Matthew, sharply with that of the Israelite elites. It is thus in obedience to the will of the Father that Jesus turns to

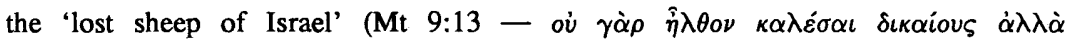
$\dot{\alpha} \mu \alpha \rho \tau \omega \lambda$ ov́s) - an obedience stripped of formalism (cf e $\mathrm{g}$ the question of keeping the Sabbath - Matthew 12:1-8; keeping the tradition of the elders - Matthew 15:1-6; service to the temple authorities - Matthew 17:24-27; 21:12-17). His service is the embodiment of the core of the demand of the 'law and the prophets' (cf Mt 22:34-40). 
He is the perfect example of the absolutely obedient 'Son of God' (Mt 5:45). As far as discipleship is concerned, the following remark by Senior is important: 'To be a disciple of this Master is not to abandon one's heritage, but to bring that heritage to its fullest potential.' The success of the disciples' executing their call to be Jesus' helpers, and the criterion that will count during the parousia, are determined by obedience to God's will - the 'law and the prophets'. It is however not obedience to the 'law and the prophets' as such that will separate the sheep from the goats (Mt 25:38). The authority of the First Testament is relevant 'only to the degree that they [the "law and the prophets"] are embodied in the commands of Jesus' (McConnell 1969:97; cf Mt 7:28f; 22:16).

Nevertheless, scholars such as McConnell (1969:90) and Kingsbury (1977:82ff) point out the paradox between Matthew 5:17-20 and Matthew 5:21-48 (the so-called 'antitheses'). We have already mentioned that Matthew 5:17-20 explicitly states that Matthew considered that it was not Jesus' intention to reduce the validity of the First Testament (cf Mt 24:35). It, however, seems that this very same positive approach regarding to the First Testament can at least not be made applicable to the third 'antithesis' - the prohibition on divorce (Mt 5:31f; cf Mt 19:3-12), the fourth 'antithesis' - the prohibition on oaths (Mt 5:33-37) - and the fifth 'antithesis' - the nullifying of the doctrine of retribution (Mt 5:38-42). Strecker (1978:69f) for example, on the basis of a traditional redaktiongeschichtliche investigation, formulates his findings by stating that it is important to note that, in the distinction between 'real' (pre-Matthean) and 'false' (redactional) antitheses, the alternatives 'tightening the Torah' or 'annulment of the Torah' do not constitute a sufficient criterion. In antithesis 1 and 2 (verse $21 \mathrm{ff}$ and $28 \mathrm{ff}$ ) the wording of the First Testament is radicalized. However, antithesis 4 (verse 33f) the First Testament oath is not only outdone, but totally abolished and antithesis 3 (verse 31f) annuls the First Testament nomism, while antithesis 5 (verse 38ff), specifically, criticizes the First Testament ius taliones. In other words, the Matthean Jesus does not mention the will of God only with regard to the Israelite tradition, but also in critical analysis of the Mosaic Torah, in order to 'fulfill' its true sense (cf Allison 1993:289-290). Other examples of the use of the First Testament in the Gospel of Matthew, like the picking and eating of the ears of corn on the Sabbath (Mt 12:1-8), the healing of the man with the shrivelled hand (Mt 12:9-14) and the interpretation of the regulations regarding what is clean and what unclean (Mt 15:1-20), can in a certain sense in this context be added to the third, fourth and fifth 'antithesis'.

Matthew uses the 'law and the prophets', as the will of the Father in heaven, to give authority to his ideological/theological perspective. In as much as Jesus as God- 
with-us is the embodiment of the will of the Father, his mission (pre-paschal and postpaschal) is cloaked with authority (see Mt 28:18). This $\dot{\varepsilon} \xi o v \sigma i \alpha$ manifests in the Moses-like teaching and the healing miracles of the Son of David. The teaching and the healings have as their content the proclamation of the gospel of the $\beta \alpha \sigma i \lambda \varepsilon i \alpha \tau \hat{\omega} \nu$ oi $\rho \alpha \nu \hat{\omega} \nu$. What is therefore remarkable is the fact that it is the fulfillment citations, in particular, which emphasize these moments of teaching and healing as the realization of the 'law and the prophets' (cf Senior 1976:674). Those fulfillment citations in Matthew 4:14ff, 8:17, 12:17ff and 13:35 (and other First Testament citations and allusions) that indicate Jesus' ministry, as well as First Testament motifs that are behind some of his christological names as indications of his task (cf Senior 1976:673; Rotfuchs 1969:121-128), cannot be seen as separate from Jesus' mission to the Israelite multitude (i e, the 'lost sheep' of the house Israel) and the Gentiles, and the opposition of the Israelite elites. The interest of some fulfilment citations indeed lies in the conviction that the life and work of Jesus, as the revelation of God's grace, is meant for the lost ones from the house of Israel as well as for the Gentiles (Rotfuchs 1969:103; cf Senior 1976:675).

The fulfillment of the 'law and the prophets' by Jesus in the Gospel of Matthew should be understood as a reduction of the First Testament to the single instruction to love one's neighbor (cf Sand 1974:192; Saldarini 1994:161). By 'reduction' I do not mean the legitimation of only a part of the First Testament, the 'core' which, according to Matthew, would be the commandment to love (see Luz 1978:400f). For Matthew, the call to love serves rather as the hermeneutic key according to which obedience to the whole 'law and the prophets' is demanded. To Matthew the authoritative explanation of the law by Jesus, in which the call to love should have precedence in all circumstances, and on which all the other laws are dependant, is crucial (Luz 1978:420).

Obedience to the call to love concretizes in the Gospel of Matthew in the ministry of the pre-paschal Jesus as Immanuel (the first sequence) with regard to the Israelite multitude in particular, but to the Gentiles as well - the indicative. During the period of the mission to all the people (the second sequence) the disciples were expected to continue this radical call to love by analogy with the example set by Jesus himself, the embodiment of absolute obedience to the will of the Father - the imperative. McConnel (1969:90) refers to this imperative which was to be realized in the ministry of disciples:

It is necessary that the disciples have a 'better righteousness' $(5: 20) \ldots$ and this means performing the commands of Jesus which primarily concern showing love to God and to one's neighbour. As the parable of the 
sheep and the goats reveals, judgement is based on whether one has shown mercy to the needy (25:31ff). Matthew emphasized that judgement takes place according to one's works or his doing the will of God (7:16-17).

The analogical continuity between the ministry of the disciples in the period of their mission to the $\pi \dot{\alpha} \nu \tau \alpha \tau \dot{\alpha} \check{\varepsilon} \theta \nu \eta$ in the second sequence and the ministry of Jesus in the first sequence thus manifests in loving care towards the Israelite multitude, while the mission to the Gentiles is assumed). This continuity and analogy between the first sequence and the second is thus dialectically based on the one hand in the presence of Jesus as Immanuel in both sequences and on the other in the obedience to the will of the Father (the 'law and the prophets') during both sequences. The Gospel of Matthew 'contains a defining dialectic: the past informs the present, and the present informs the past' (Allison 1993:289). As far as the first sequence is concerned: 'His [Jesus Immanuel's] bond with the disciples [and thus with the church] is repeatedly stressed by means of ... catch phrases such as "with them", "with you", "with me". And the abiding presence of Jesus ... is a promise without end $(18: 20 ; 28: 20) \ldots$ the risen Lord is present wherever a community of people hear the gospel and respond with ... compassion and service' (Senior 1976:676). As far as the latter sequence is concerned, Jesus' way is the disciples' way, and the congregation who follows suit is reminded by Matthew, as by his predecessors, of the consequences of the following of Jesus. The following demands an instruction about its reason and meaning, which is strongly emphasized in Matthew's gospel through the five discourses which are referred to in Matthew 28:20 ( $\approx \dot{\alpha} \nu \tau \alpha \dot{o \sigma} \sigma \alpha \dot{\varepsilon} \nu \varepsilon \tau \varepsilon i \lambda \dot{\alpha} \mu \eta \nu \dot{\nu} \mu \hat{\imath} \nu$ ). The content of this instruction is God's longstanding will. As Jesus fulfilled it totally, so the disciples are called upon to fulfill God's will, which includes 'being with him' (Frankemölle 1974:82).

The closing words (Mt 13:52) of the parable discourse (Mt 13:1-51) express this analogy between the Jesus-image and the disciple-image, based in the radicalized Jesusinterpretation of the 'law and the prophets' (the 'old' and the 'new' in one): 'Therefore every teacher of the law who has been instructed about the kingdom of heaven is like the owner of a house who brings out of his storeroom new treasures as well as old' (Mt 13:52). The disciples are reminded of how Jesus in his teaching and work made the old things new and how he interpreted old traditions in a radically new way and are thus informed of how they should go about with what they already know but also with their newly acquired knowledge of the kingdom (Vorster 1977:136). The sequence in Matthew 13:52 should be noted: new and old! "What then is "old"? The Jewish connotation of the term "scribe" suggests that, with "old", Matthew is referring to the "law and the prophets" which, in the opinion of the evangelist, remain valid for 
Christians (see 5:17-20 [cf Van Tilborg 1986:48-52]). The understanding disciple is the Christian scribe who, with the new as criterion, preserves the old. He "brings forth" from his treasure new and old, that is, he explains it and makes it known to others' (Lambrecht 1992:173-174).

Within the framework of the sequence of the pre-paschal Jesus commission Jesus functions as the protagonist's obedience to the 'law and the prophets' against the dis-

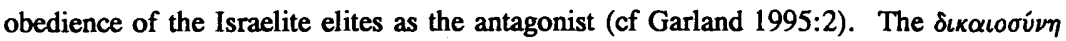
of the Israelite elites, as the so-called 'sons of the kingdom' and 'teachers of the law of Moses', manifests generally as external formalistic show, without love for the outcasts. The disciples as Jesus' assumed helpers are warned against the $\delta i \delta \alpha \chi \dot{\eta}$ of these elites

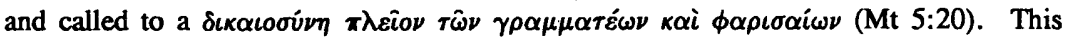
amounts to the following:

Both the disciples and the scribes and Pharisees have righteousness ... This, however, does not mean that the righteousness of the two groups is identical. Jesus demands that the righteousness of the disciples is to exceed that of the scribes and Pharisees. This does not mean that the disciples are to live according to a different law but that they are to live according to a different interpretation of the law ... The goal of this type of conduct is perfection ... The disciples are to observe everything that Jesus commanded.

(Przybylski 1980:87)

The consequence is that the call to obedience to the will of God, as expressed in the 'law and the prophets', is present in both sequences, amid an analogically continuing opposition (see Aguirre 1981:152f). Jesus, as the embodiment of the will of God, is obedient unto death on the pre-paschal temporal level. The same must be said of the disciples during their post-paschal commission. 'The disciples of Jesus have acquired both Israel's promises and its job' (Garland 1995:9). In this event, the risen Jesus is God-with-us until the completion of the age.

\section{WORKS CONSULTED}

Aquirre, R 1981. Cross and kingdom in Matthew's theology. Theological Digest 29, 149-155.

Allison, D C, Jr 1985. The end of the ages has come: An early interpretation of the passion and resurrection of Jesus. Philadelphia: Fortress.

1993. The new Moses: A Matthean typology. Minneapolis: Fortress. 
Barr, D L 1976. The drama of Matthew's gospel: A reconsideration of its structure and purpose. ThD 24, 349-359.

Barth, G 1961. Das Gesetzesverständnis des Evangelisten Matthäus, in Bornkamm, G et al, Überlieferung und Auslegung im Matthäusevangelium, 54-154. 2.Auflage. Neukirchen: Neukirchen Verlag.

Charlesworth, J H 1985. Introduction for the general reader, in Charlesworth, J H (ed), The Old Testament Pseudepigrapha, Volume 2: Expansions of the 'Old Testament' and legends, wisdom and philosophical literature, prayers, psalms, and odes, fragments of lost Judeo-Hellenistic works, xxi-xxxiv. Garden City, NY: Doubleday.

Conzelmann, H 1977. Die Mitte der Zeit: Studien zur Teologie des Lukas. 6.Auflage. Tübingen: Mohr.

Crossan, J D 1986. From Moses to Jesus: Parallel themes. Bible Review 2/2, 18-27.

1994. The infancy and youth of the Messiah, in Shanks, H (ed), The search for Jesus: Modern scholarship looks at the Gospels, 59-81. Washington, DC: Biblical Archaeological Society.

Frankemölle, H 1974. Jahwebund und Kirche Christi: Studien zur Form- und Traditionsgeschichte des 'Evangeliums' nach Matthäus. Münster: Aschendorf.

Garland, D E 1995. Reading Matthew: A literary and theological commentary on the First Gospel. New York: Crossroad.

Gibbs, J M 1968. The Son of God as the Tora incarnate in Matthew, in Cross, F L (ed), Studia Evangelica, 38-46. Berlin: Akademie. (Studia Evangelica 4.)

Hamerton-Kelly, R G 1972. Attitudes to the law in Matthew's gospel: A discussion of 5:18, $B R$ 17, 19-32.

Harrington, D J 1985. Pseudo-Philo, in Charlesworth, J H (ed), The Old Testament Pseudepigrapha, Volume 2: Expansions of the 'Old Testament' and legends, wisdom and philosophical literature, prayers, psalms, and odes, fragments of lost Judeo-Hellenistic works, 297-377. Garden City, NY: Doubleday.

Hare, D R A 1985. The lives of the prophets, in Charlesworth, J H (ed), The Old Testament Pseudepigrapha, Volume 2: Expansions of the 'Old Testament' and legends, wisdom and philosophical literature, prayers, psalms, and odes, fragments of lost Judeo-Hellenistic works, 379-399. Garden City, NY: Doubleday.

Isaac, E 1983. 1 (Ethiopic Apocalypse of) Enoch, in Charlesworth, J H (ed), The Old Testament Pseudepigrapha, Volume 1: Apocalyptic literature and Testaments, 589. London: Darton, Longman \& Todd.

Kingsbury, J D 1973. The stracture of Matthew's gospel and his concept of salvationhistory. $C B Q 35,451-474$. 
Kingsbury, J D 1975a. Matthew: Structure, christology, kingdom. Philadelphia: Fortress.

- 1977. Matthew. Philadelphia: Fortress.

Klijn, A F J 1983. 2 (Syriac Apocalypse of) Baruch, in in Charlesworth, J H (ed), The Old Testament Pseudepigrapha, Volume 1: Apocalyptic literature and Testaments, 615-652. London: Darton, Longman \& Todd.

Lambrecht, J [1991] 1992. Out of the treasure: The parables in the Gospel of Matthew. Louvain: Peeters Press. (Louvain Theological \& Pastoral Monographs 10.) Lohmeyer, E 1942. Kultus und Evangelium. Göttingen: Vandenhoeck \& Ruprecht. Luz, U 1978. Die Erfüllung des Gesetzes bei Matthäus (Mt 5:17-20). ZThK 75, 398435.

1994. Matthew in history: Interpretation, influence, and effects. Minneapolis: Fortress.

Marxsen, W 1959. Der Evangelist Markus: Studien zur Redaktionsgeschichte des Evangeliums. Göttingen: Vandenhoeck \& Ruprecht.

McConnel, R S 1969. Law and prophecy in Matthew's gospel: The authority and use of the Old Testament in the Gospel of St Matthew. Basel: Reinhardt.

Meeks, W A 1070. Moses as God and King, in Neusner, J (ed), Religions in antiquity: Essays in memory of Enwin Ramsdell Goodenough, 354-371. Leiden: Brill.

Meier, J P 1975. Salvation-history in Matthew: In search of a starting point. CBQ 37, 203-15.

1976. Law and history in Matthew's gospel: A redactional study of Matthew 5: 17-48. Rome: Biblical Institute.

Petersen, N. R 1980. Orientation by disorientation: Studies in literary criticism and biblical literary criticism, in Spencer, R A (ed), Orientation by disorientation: Studies in literary criticism and biblical literary criticism, 25-50. Presented in honor of William A Beardslee. Pittsburgh: Pickwick.

Przybylski, B 1980. Righteousness in Matthew and his world of thought. Cambridge: Cambridge University Press.

Rengstorf, K H 1969. Das Evangelium nach Lukas. 14.Auflage. Göttingen: Vandenhoeck \& Ruprecht. (Das Neue Testament Deutsch 3.)

Rothfuchs, W 1969. Die Erfühlungszitate des Matthäus-Evangeliums: Eine Biblisch theologische Untersuchung. Stuttgart: Kohlhammer.

Saldarini, A J 1994. Matthew's Christian-Jewish community. Chicago: The University of Chicago Press.

Sand, A 1974. Das Gesetz und die Propheten: Untersuchungen zur Theologie des Evangeliums nach Matthäus. Regensburg: Pustet. 
Stanton, G N 1992. A gospel for a new people: Studies in Matthew. Edinburgh: T \& T Clark.

Senior, D P 1976. The ministry of continuity: Matthew's gospel and the interpretation of history. BiTod 82, 670-676.

Strecker, G 1966. Der Weg der Gerechtigkeit: Untersuchung zur Theologie des Matthäus. 2.Auflage. Göttingen: Vandenhoeck \& Ruprecht.

Trilling, W 1964. Das wahre Israel: Studien zur Theologie des Matthäus-Evangeliums. 2.Auflage. München: Kösel.

- 1969a. Die Tod Jesu: Ende der alten Weltzeit (Mk 15,33-41), in Trilling, W (Hrsg), Christusverkdindigung in den synoptischen Evangelien: Beispiele gattungsgemässer Auslegung, 191-211. München: Kösel.

- 1969b. Die Auferstehung Jesu: Anfang der neuen Weltzeit (Mt 28: 1-8), in Trilling, W (Hrsg), Christusverktundigung in den synoptischen Evangelien: Beispiele gattungsgemässer Auslegung, 212-243. München: Kösel.

Uspensky, B 1973. A poetics of composition: The structure of the artistic text and typology of a compositional form, translated by S Wittig. Berkeley: University of California Press.

Van Aarde, A G 1994. God-with-us: The dominant perspective in Matthew's story, and other essays. Pretoria: University of Pretoria. (HTS Suppl 5.)

Van Tilborg, S 1986. The Sermon on the Mount as an ideological intervention: A reconstruction of meaning. Assen: Van Gorcum.

Vorster, W S 1977. The structure of Matthew 13. Neotestamentica 11, 130-138.

- 1981. The function of the use of the Old Testament in Mark. Neotestamentica 14, 62-72.

Waetjen, H C 1976. The origin and destiny of humanness: An interpretation of the Gospel according to Matthew. San Rafael, CA: Crystal Press.

Walker, R 1967. Die Heilsgeschichte im ersten Evangelium. Göttingen: Vandenhoeck \& Ruprecht. 